\title{
TCOM \\ Spikey blobs with evil grins: understanding portrayals of the coronavirus in South African newspaper cartoons in relation to the public communication of science
}

\section{Marina Joubert and Herman Wasserman}

Abstract

Keywords

DOI

Introduction
This study explores how South African newspaper cartoonists portrayed the novel coronavirus during the initial months of the COVID-19 pandemic. We show how these cartoons respond to the socio-economic and cultural contexts in the country. Our analysis of how cartoonists represent the novel coronavirus explain how they create meaning (and may influence public sentiments) using colour, morphological characteristics and anthropomorphism as visual rhetorical tools. From a total population of 497 COVID-19-related cartoons published in 15 print and online newspapers from 1 January to 31 May 2020, almost a quarter $(24 \% ; n=120)$ included an illustration of the coronavirus. Viruses were typically coloured green or red and attributed with human characteristics (most often evil-looking facial expressions) and with exaggerated, spikey stalks surrounding the virus body. Anthropomorphism was present in more than half of the 120 cartoons where the virus was illustrated ( $58 \% ; n=70$;), while fear was the dominant emotional tone of the cartoons. Based on our analysis, we argue that editorial cartoons provide a useful source to help us understand the broader discursive context within which public communication of science operates during a pandemic.

Science and media; Science and technology, art and literature; Visual communication

https://doi.org/10.22323/2.19070208

Submitted: 30th June 2020

Accepted: 14th September 2020

Published: 14th December 2020

Would it have been easier if we could see the damn virus all around us; if it was red and prickly, and stuck to us like blackjacks? asks South African science journalist Elsabé Brits in Vrye Weekblad, an Afrikaans-language online newspaper [Brits, 2020]. It is reasonable that people feel aggravated by an invisible enemy that has caused global disruption and widespread hardship.

The nature of viruses as an invisible, potentially deadly, threat explains our fascination with viruses and the prevalence of virus metaphors in popular culture 
(for example, 'computer viruses' or 'viral videos'); as well as the common occurrence of lethal viruses as villains in science fiction and movies such as Outbreak and Contagion [Schell, 1997]. In Fever, ${ }^{1}$ a 2016 thriller by South African author Deon Meyer, the storyline of widespread havoc and devastation caused by a deadly virus now almost seem like a disconcertingly accurate depiction of what was to come in 2020.

This article explores South African editorial cartoons in the context of COVID-19, and specifically how newspaper cartoonists illustrate the virus and use anthropomorphism as a visual rhetorical device to communicate aspects of the virus and articulate responses to it.

Given that our increasingly sophisticated abilities to visualise viruses have transformed our understanding of and response to viruses, we start with a brief reference to the theory of social representation of science, followed by a concise summary of historical milestones that have paved the way for our current capabilities to visualise viruses.

Next, we look at the role of editorial cartoons, and their potential contribution to public communication of science. We discuss anthropomorphism as one of the key tools used by cartoonists to engage readers.

Finally, the focus of the current study is an analysis of the anthropomorphic portrayal of the novel coronavirus in South African editorial cartoons, published from January to May 2020. We analyse the incidence and nature of how the virus is anthropomorphised as an indicator of public sentiment about the novel coronavirus and COVID-19.

We conclude with a discussion of the implications of anthropomorphising the coronavirus for public understanding of the science behind COVID-19.

Theoretical perspective

A theoretical understanding of social representations of science helps us to understand the processes whereby abstract ideas and objects are made more concrete until they are assimilated into general culture [Moscovici, 1961; Moscovici, 1984; Höijer, 2011]. Bauer and Gaskell [1999] argue that things or ideas are typically 'represented' when they are absent or hidden from sight, adding that an original idea may take on multiple forms in different pragmatic contexts. In a reflection on social construction of scientific realities, Sismondo [2010] elaborates on how materials are manipulated in laboratories to create new shapes and beautiful objects that are created to emphasize specific characteristics and may, therefore, be very different from the original images produced in the laboratory. These processes are clearly at work when viruses are visualised by artists and/or illustrators (including cartoonists). Consequently, our current understanding of and our responses to viruses are shaped by the scientific images and artistic renditions created by scientists and artists.

In the case of the novel coronavirus, visualisations often go further than scientific depictions to include artistic impressions, as in the case of editorial cartoons. In

\footnotetext{
${ }^{1}$ See https://www.deonmeyer.com/b_fever.html.
} 
addition to providing a descriptive rendering of the virus in an accessible format to mass audiences, these cartoons articulate popular sentiment and add an interpretive layer of meaning within discursive contexts. Because they are created to appeal to a general readership, editorial cartoons about COVID-19 provide a perspective on the cultural and social meanings of such a pandemic, and the many nuances of the multifaceted relationship between a pandemic and culture. Understanding the multiple and nuanced linkages between culture and disease is a prerequisite for preventing, controlling or mitigating epidemics [Wald, Tomes and Lynch, 2002; Alcabes, 2009].

\section{Milestones} towards visualising viruses
In a reflection on how we depict COVID-19, Chatterjee [2020] describes the "cloak of invisibility" that surrounds the novel coronavirus as a fierce weapon, allowing it to multiply, invade and threaten us without being seen. It is therefore understandable that the natural history of viruses is characterised by efforts to visualise this threat. A brief look at the history of our abilities to visualise viruses highlight how historical advances have shaped this relationship and how current technologies continue to influence how we view viruses.

The world first got to see images of the novel coronavirus in January 2020, about a month after the World Health Organisation (WHO) was informed of a new disease that first emerged in China [World Health Organisation, 2020]. Soon after, these images began circulating in the media. That detailed images of this virus could enter the public domain so swiftly, is thanks to the development of microscopic imagery over the course of several centuries, and recent advances in visualisation techniques.

The earliest microscopes go back to around 1600, but these were little more than magnifying glasses and were regarded as curious toys, rather than being used for systematic observations that contributed to scientific knowledge [Ball, 1966]. This changed when, in the $17^{\text {th }}$ century, Antony Van Leeuwenhoek crafted a single-lens microscope that could magnify up to 300 times [Fildes, 1951; Gest, 2004]. In Victorian times, gazing through microscopes became a popular hobby in Great Britain, as people were fascinated by a previously unseen world teeming with tiny living creatures [Campbell, 2018]. Until the mid-19 ${ }^{\text {th }}$ century, people had no idea that bacteria, yeasts and viruses could cause disease and death. In busy hospitals, doctors and nurses moved from one patient and surgical procedure to the next without washing their hands, unaware that they were spreading lethal infections. The idea of washing hands as a hygiene protocol was scorned by the medical profession [Tan et al., 2020]. In visual imagery of the time, diseases were depicted as terrifying evil spirits [Ulaby, 2020].

In the late 1850s, Louis Pasteur demonstrated the role of microorganisms (in this case bacteria) in fermentation and putrefaction, thereby laying the foundations for microbiology as a modern scientific discipline [Artenstein, 2012].

Germ theory - i.e. the notion that diseases are caused by invisible minute organisms, or germs - met with considerable public resistance, especially in the U.S. [Richmond, 1954; Tomes, 1997]. The mass media, and particularly women's magazines, played an important role in creating public awareness and wider acceptance of germ theory and domestic hygiene practices [Tomes, 1990]. In Queen 
of the Home, published in 1889, magazine editor and author, Emma Churchman Hewitt, wrote that germ theory "placed in the hands of everyone, if not the power of destroying these germs, at least the power to prevent their proliferation" [Tomes, 1999, p. 67].

In the early 1930s, the first transmission electron microscope was built and used to produce images of bacteria; eight years later, it was used to capture images of a virus [Ackermann, 2011; Buiani, 2014]. Current advances in microscopy allow us to see the detailed structure of viruses, thereby helping scientists to develop treatments and vaccines [Goldsmith and Miller, 2009].

In 1967, virologists June Almeida and David Tyrrell were the first to describe previously unknown virus particles characterised by a "distinct layer of projections" (i.e. coronaviruses) [Almeida and Tyrrell, 1967, p. 176]. Today, we have detailed images of coronavirus particles with the characteristic fringe of protruding clumps that create the effect of a halo, or corona, ${ }^{2}$ around the virus [Nerlich, 2020].

A month after Chinese health officials informed the WHO in December 2019 of 44 patients with a mysterious form of pneumonia [World Health Organisation, 2020], the first images of the novel coronavirus [Gale, 2020] were released, with other laboratories around the world producing similar images soon afterwards (see Figure 1a \& b). Subsequently, leading laboratories around the world have created electron micrographs and artistic renditions of this virus. These images, described by Frumkin [2020] as ghostly black-and-white tracings of the invisible, bear little resemblance to the bright and colourful depictions of the novel coronavirus that were subsequently widely portrayed in the media.

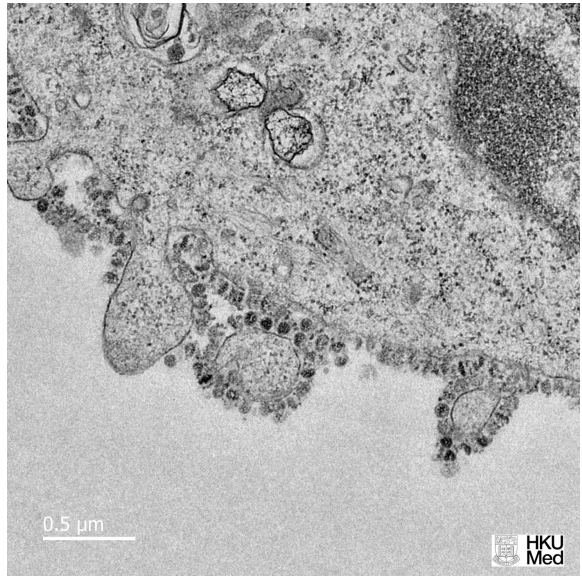

(a)

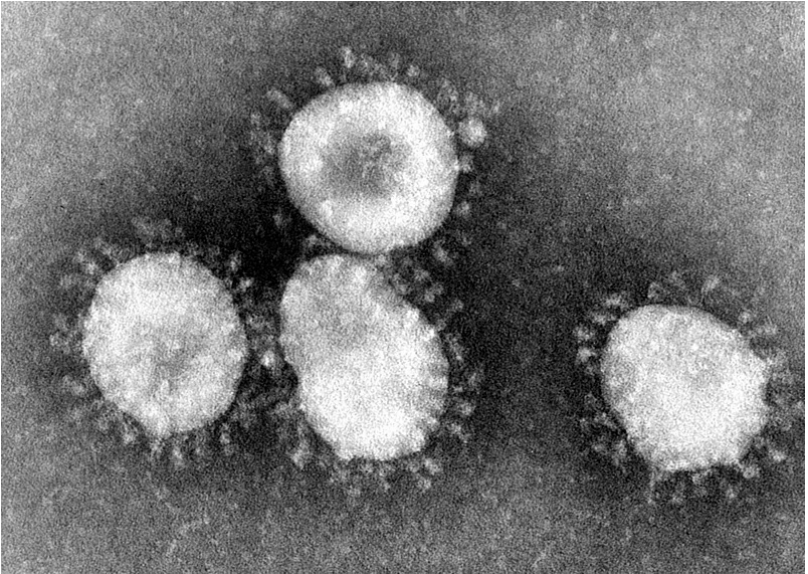

(b)

Figure 1. Electron micrographs of the 2019 novel coronavirus (Source: The University of Hong Kong (1a, left) and Centers for Disease Control and Prevention (1b, right)).

At first, all electron micrographs were produced in black and white and had to be stained afterwards [Weaving, 2020]. In 2016, scientists developed a way of capturing these images in colour by staining cellular components with metal ions that emit unique signals, which can then be rendered as vivid colours [Adams

\footnotetext{
${ }^{2}$ One of the meanings of the word 'corona' is 'something suggesting a crown' (Source: Online Merriam-Webster Dictionary; see https:/ / www.merriam-webster.com/dictionary/corona).
} 
et al., 2016]. Alternatively, scientists add colour later to make the images clear and vivid, but the choice of colours are arbitrary as can be seen in Figure $2 \mathrm{a}$ and $2 \mathrm{~b}$ for example.

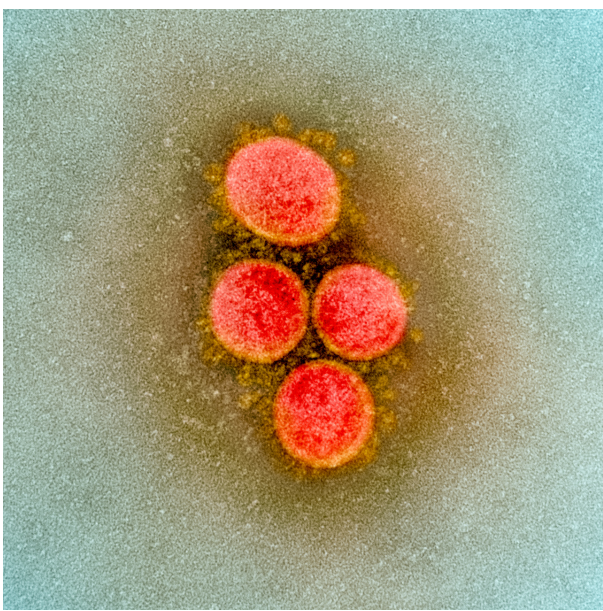

(a)

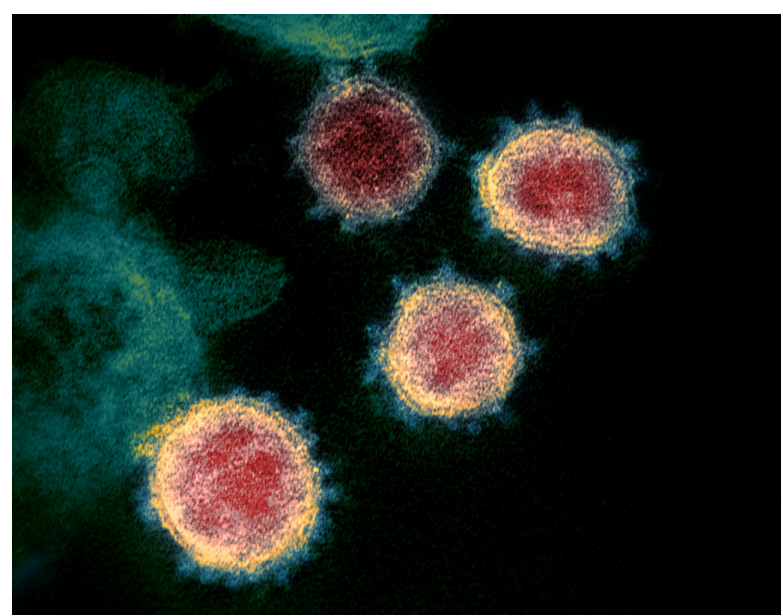

(b)

Figure 2. Colour-enhanced transmission electron micrographs of SARS-CoV-2 virus particles. (Source: The National Institute of Allergy and Infectious Diseases).

Based on the structural information obtained through sophisticated imaging techniques, artists at the Centers for Disease Control and Prevention produced a high-resolution graphic of the novel coronavirus (or SARS-CoV-2) that has been widely used in the media (see Figure 3).

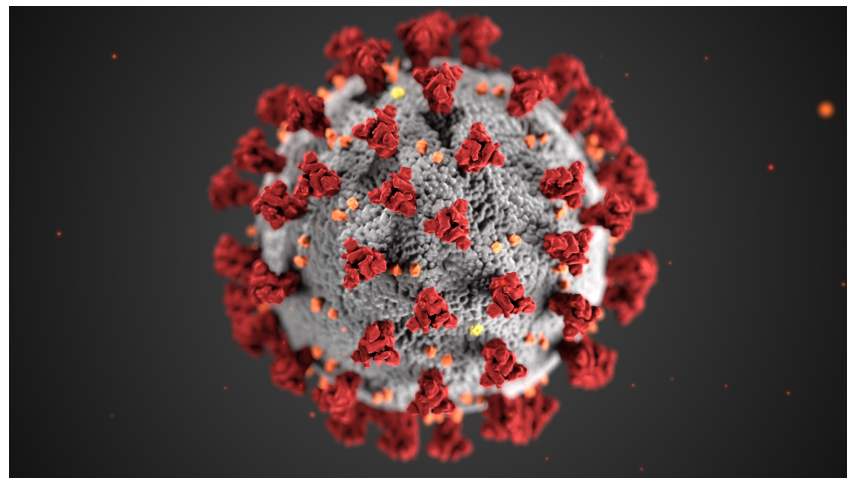

Figure 3. An illustration of the ultrastructural morphology exhibited by novel coronaviruses. (Source: Centers for Disease Control and Prevention).

There are multiple and intricate steps in the process of transforming data retrieved from a microscope into a visible image of a virus, with several elements of interpretation involved along the way.

Scientists and illustrators use artificial colours for technical reasons, but also to add aesthetic and media appeal to their pictures. Ultimately, the way the virus is drawn (or illustrated) depends on what it looks like under the microscope, as well as choices and assumptions made by the artist. These choices can affect public fears and anxieties about infectious diseases. Therefore, visualisations of viruses are more than mere illustrations; they have socio-cultural dimensions [Buiani, 2014; 
Frumkin, 2020]. For example, Weaving [2020] points out that, if we were willing to accept that objects captured in the sub-microscopic world (i.e. the realm that viruses inhabit) are essentially monochrome grey, viruses would seem less like hostile invaders. Instead, we typically depict viruses in bold colours which portray them as aggressive and noxious substances and contribute to a culture of fear that surrounds them [Buiani, 2014]. Similarly, cartoonists choose specific colours when they draw the virus in order to elicit a specific response from readers. In addition to the choice of colour, other artistic devices such as anthropomorphism contribute to the media discourse around the virus and, ultimately, articulate and shape popular understandings of science.

Anthropomorphism - origins, merits and concerns
Anthropomorphism refers to the phenomenon whereby authors or artists attribute human characteristics to non-human animals and non-living or inanimate objects [Byrne, Grace and Hanley, 2009]. This includes physical characteristics and abilities, for example a talking dog or a dancing teapot, as well as mental characteristics and abilities, for example a sad tree or an angry virus.

Scientific consensus dictates that coronaviruses are merely minute bundles of genetic material that exist only to replicate. Thus, there is no thought, intent or capacity for malice on the part of the virus; it cannot be sneaky, evil or aggressive; viruses cannot attack us or wage a war against us [Porubanova and Guthrie, 2020]. As stated by Philp [2020], the virus does not exist to kill or harm, those are just its side effects. But, as is true for a multitude of non-human beings and inanimate objects, people frequently attribute human-like characteristics and traits to microbial life forms and viruses, including physical and psychological features, as well as human behaviours and cognitive states [Epley, Waytz and Cacioppo, 2007; Wood, 2019].

The inclination to anthropomorphise viruses during disease outbreaks is not new. Moodley and Lesage [2019] studied how newspapers in South Africa represented the 2014 outbreak of Ebola and found that the Ebola virus was frequently portrayed as a predator and criminal. Similarly, Connelly and Macleod [2003] showed how newspaper reports afforded agency to the Aids virus, allowing for its construction as the enemy, and inciting citizens to take on a preventative and caring role.

Perhaps the widespread occurrence of anthropomorphism is evidence that we, as human beings, think of ourselves as the most important beings (i.e. anthropocentrism) and that is why we interpret any experience from a human viewpoint [Byrne, Grace and Hanley, 2009]. Another explanation is that anthropomorphism is simply a way of reasoning about an unfamiliar entity in terms of a human framework [Epley, Waytz, Akalis et al., 2008]. In other words, we make sense of something by making that entity sentient, which satisfies our collective need to control our environment, a phenomenon known as effectance motivation [Waytz et al., 2010].

From the perspective of the cognitive processes underlying anthropomorphism, Airenti [2018] defines anthropomorphism as a relation that humans establish with non-human entities as if they were human beings. In doing so, we put the non-human entity "in the position of interlocutor in an imaginary communicative situation" [Airenti, 2018, p. 9]. In the course of this process, we automatically attribute intentionality and social behaviour to these entities. The author argues 
that all of us, from young children to adults, have a basic tendency to anthropomorphise and that anthropomorphism, therefore, is a "specific human attitude, not a childish mistake" [Airenti, 2018, p. 7].

As a literary device, anthropomorphism is particularly widespread in children's books, and is mostly applied to animals. The use of anthropomorphism boomed when Disney started producing animated cartoon films with mice, rabbits, piglets, wolves and many other species talking, walking, dancing, arguing, and more [DoRozario, 2006]. Our tendency to anthropomorphise animals is not surprising, given that we have lived in close proximity to wild and domestic animals for centuries, and that we rely on animals for food, transportation and labour, but also for companionship, protection and entertainment [Breedlove and Arguin, 2015]. Notably, zoonoses (the transfer of diseases from animals to humans) inevitably result from these close interactions.

Pedagogically, anthropomorphism can be a useful tool to humanise science, making it more accessible to learners. Hight [2017] demonstrated that, in documentary films, anthropomorphism helped viewers to recall content more accurately, without creating anthropomorphic attitudes towards the films' content, concluding that anthropomorphism is a useful tool for communicating science, engaging audiences and increasing content absorption without compromising the integrity of the information.

Wood [2019] presents a perspective on the popularity and ubiquity of anthropomorphism in Japanese culture, including its widespread use in public communication of science. Examples include talking test tubes, smiling proteins, plant hormones with personalities and atomic particles wearing hats and sunglasses. Japanese explanations of how influenza is transmitted include virus particles "represented with evil, grinning faces and pitchforks, gleefully attacking their victims" [Wood, 2019, p. 25]. However, anthropomorphism occurs across all cultures and types of literature, including academic texts. Dealing with forms of life that people can't see but that affect their daily lives, the field of microbiology is particularly susceptible to the use of anthropomorphic terminology [Davies, 2010]. Examples from microbiology research include reports of screaming yeasts [Roosth, 2009], hungry fungi that attack iron [Hand, 2016], dancing bacteria [Talib et al., 2017] and rock-eating bacteria [Smith, 2018].

While many scientists acknowledge the potential of anthropomorphism as a tool to increase empathy with non-human species, they also point out that it may lead to inaccurate understanding of biological processes in the natural world [Milman, 2016]. Negative judgments about anthropomorphism range from describing it as a mild vice that a well-educated person should avoid [Bruni, Perconti and Plebe, 2018], to viewing the phenomenon as something that is potentially misleading and even an example of bad science [Arbilly and Lotem, 2017]. For example, in the case of microorganisms, children's anthropocentric conceptions are primarily related to the roles of microbes as agents of disease, resulting in a mostly negative perspective [Byrne, Grace and Hanley, 2009] which is appropriate for viruses, but not always correct in the case of bacteria and yeasts. In the context of disease prevention and control, it is pointed out that a view of viruses as predators that can stalk their victims is misleading, since it warps our understanding of the role that we, as humans, play as vectors for spreading the virus [Weldon, 2001]. 
Anthropomorphising Two distinctive features make the coronavirus instantly recognisable: the virus is the coronavirus shaped like a sphere and it is surrounded by a halo of lumps. These structural features are usually more pronounced in artists' impressions compared to the images we see in electron micrographs. In the first few months of 2020, a global explosion of artworks depicting coronavirus particles established a rendition of these 'spikey balls' as an iconic image of a virus that disrupted life around the globe [Gaiter, 2020; Nerlich, 2020].

When cartoonists draw the novel coronavirus, they often go a step further. In addition to bold and bright colours and exaggerated features, they add human characteristics, motivations, behaviours and emotional expressions - i.e. they anthropomorphise the virus. The attribution of anthropomorphic characteristics to invisible pathogens such as bacteria or viruses is a common occurrence, especially when we are faced with uncertainty and fear [Airenti, 2018].

There are many reasons why artists may choose to anthropomorphise a virus. Broadly speaking, anthropomorphism could help us to make sense of a complex, confusing and unpredictable world [Porubanova and Guthrie, 2020]. In the case of the coronavirus, thinking of the virus as human-like, gives us a way to grasp these unseen entities and, even if this grasp is just an illusion, it provides us with some sense of confidence and control. More specifically, depicting the coronavirus as a clever genius or devious adversary that is actively plotting against us, may help people to rally together against a common enemy [Philp, 2020]. If the threat is portrayed as sentient, people may be more willing to comply with precautionary measures and tolerate treatments [Schlozman, 2014]. Similarly, Kim and McGill [2011] demonstrated that when diseases are described as having evil intentions to hurt us, it affected the level of risk people perceived, and this, in turn, depended on their individual perceived power to control the risk. Furthermore, adding human traits to a virus, could be a way to add emotional engagement and evoke a response. For example, illustrating the virus with an evil grin or an aggressive pose clearly emphasises the threat, while drawing the virus as cute and endearing could be a way to assuage public fears [Ulaby, 2020]. However, it can also be misleading to draw the virus as something reassuring and friendly that almost resembles a toy [Gaiter, 2020]. In general, it could be argued that giving the virus a 'face' makes it more 'real' and may encourage people to adhere to hygiene protocols such as wearing masks, washing hands regularly and keeping a physical distance from others.

In the South African context, cartoonists also use anthropomorphism as a tool to contextualise scientific information and reflect public sentiment within the prevailing social, political and economic contexts. By paying attention to these anthropomorphic elements, it may become evident not only what the prevailing understanding of scientific information is, but also what attitudes, anxieties, fears and misconceptions may be present in popular discourses. 
Defining editorial cartoons, as well as their roles and relevance to science communication
Analysing the socio-cultural meaning of South African cartoons on COVID-19
Editorial cartoons (also known as newspaper cartoons or political cartoons) are persuasive visual summaries that intelligibly condense and simplify a current issue into one depiction in a form that is easily understood by the general public [Medhurst and DeSousa, 1981; Wigston, 2002; Giarelli and Tulman, 2003]. Cartoonists get their ideas and inspiration from the daily flow of news, events and issues in the political, economic, cultural and societal arenas [Wiid et al., 2016]. Most editorial cartoons present a single message or perspective and are drawn within a single frame (or border), which differentiates them from comic strips that typically have storylines spanning a series of frames.

DeSousa and Medhurst [1982] describe the primary function of (political) cartooning as showing the interrelationships of people, events and power, and add that cartoonists tap into the collective consciousness of readers, thereby reaffirming cultural values and our individual interpretations of those values. These cartoons may help readers to interpret their experiences of the world at a specific time [Greenberg, 2002] and reflect contemporary cultural attitudes and values [Giarelli and Tulman, 2003]. During difficult times, cartoonists may also offer hope and encourage solidarity [The Economist, 2020].

As a form of visual news discourse, editorial cartoons not only comment on current events, but also express concern, criticism and frustration, question those in power and provoke people to react against injustice, often with a satirical and/or comical slant [Kotzé, 1988; Kleeman, 2006; Knieper, 2007; Panneerselvan, 2020]. Cartoons, furthermore, are a visual record of history that helps to construct the rhetoric related to a specific topic or issue [Kelley-Romano and Westgate, 2007].

Reflecting on the role of cartoons from the $19^{\text {th }}$ century in public health advocacy, Hansen [1997] points out that, in the second half of this century, profound changes in our understanding of infectious diseases coincided with the golden age of political cartooning. Instead of an exclusive focus on professional writing, the author suggests that cartoons are a significant source that reveal how ordinary people understand a specific health issue and provide some insight into their circumstances and challenges while facing a health issue. Hansen draws attention to the advocacy role of cartoons, and their role in identifying problems and assigning responsibility for such problems.

Around the globe, newspaper cartoonists have responded to the COVID-19 pandemic and contributed to the discourse by capturing and commenting on the political and societal impacts and responses in their work. The same is true in South Africa, a country with a strong tradition of award-winning editorial cartooning. This provided a unique opportunity to study how South African cartoonists represent a science-related issue that is closely interwoven with politics and society.

The ability of editorial cartoons to capture public sentiment at a specific point in time is illustrated in South African editorial cartoons that reflect the societal impact of the pandemic on the society. Amongst the first few cases of COVID-19 in South Africa were seven people (out of a group of 10 people traveling together) who returned to Durban, South Africa, on 1 March 2020, after a ski holiday in Italy. As numbers started climbing in South Africa, journalist Sizwe Dhlomo took to social media with the claim that it was the rich who brought the coronavirus to South 
Africa, but the poor who would suffer the most [Entertainment Reporter, 2020]. This notion, of the rich infecting the poor, was depicted by cartoonist Brandan Reynolds in his cartoon 'The rich', which shows a jet plane seeding the virus over an informal settlement (Figure 4). As signalled by this cartoon, which was published early in the pandemic, the media discourse around COVID-19 in South Africa would be shaped by the socio-economic and political contexts in one of the world's most unequal countries. This highlights the importance of understanding the public communication of science within particular contexts. Rather than relying on the provision of factual information as a way to counter disinformation and improve public understanding in a one-size-fits-all approach, science communication needs to reckon with the specific conditions of its reception and interpretation.

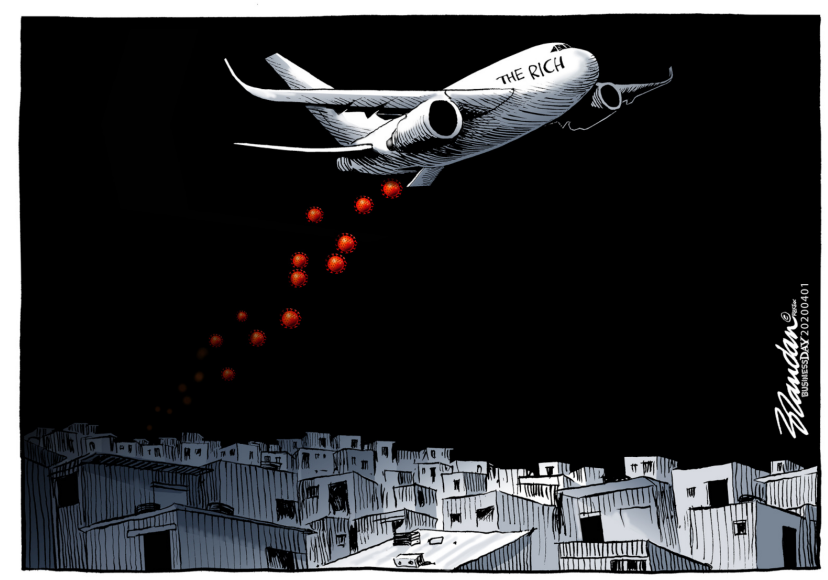

Figure 4. "The rich", by Brandan Reynolds, published in Business Day on 1 April 2020. Used with permission.

Editorial cartoons can communicate issues that would be difficult to articulate in written texts. Previous experience in South Africa, such as during the HIV / Aids struggle, showed how cartoons can play a vital role in combating disease [Wigston, 2002; Horne, 2011]. Globally, comics and graphic novels have offered pathways to improve health literacy [e.g. Tatalovic, 2009; Green and Myers, 2010; Tarver et al., 2016; McNicol, 2017; Farinella, 2018]. By distilling complex issues into a form accessible to a non-expert audience [Kleeman, 2006; Kelley-Romano and Westgate, 2007; Domínguez, 2014], editorial cartoons constitute a form of public science communication.

Representations of scientific information are, however, bound up with other contextual socio-cultural dynamics. In the context of the coronavirus pandemic, science communication was engaged in a struggle for discursive dominance over disinformation campaigns, conspiracy theories and anecdotal speculation. A cartoon from the current dataset (see Figure 5) draws attention to the dangerous spread of disinformation alongside the spread of the virus. The cartoon, by Jonathan Shapiro (drawing under the pen name Zapiro), depicts a virus-like figure labelled 'Fake News Virus', that dwarfs the coronavirus, suggesting that misinformation and conspiracy theories may pose an even bigger danger to society. This cartoon could be read as an implicit commentary on the limits of popular science communication such as editorial cartooning itself, even as it attempts to issue a warning that only authoritative, legitimate sources of information should be trusted. 


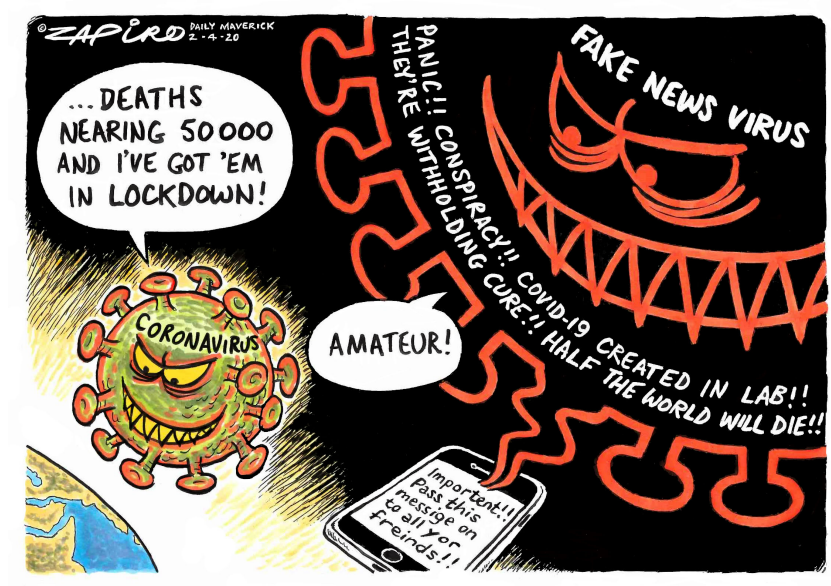

Figure 5. "Fake news virus", by Zapiro, published in Daily Maverick on 2 April 2020. Used with permission. (C) 2020-2020 Zapiro (all rights reserved).

Cartoonists employ a variety of tools, such as paradox, irony, humour and exaggeration to deliver a specific message at a specific time [Giarelli and Tulman, 2003]. In the African context, cartoonists have been noted to appropriate the global conventions of caption, (indirect) allusion, exaggeration (caricature), symbolism and pseudonym, and combine them with contextual communicative norms and socio-cultural aesthetics, which may include allusions to local issues, the use of popular catch phrases, and employment of local lingua franca [Oduro-Frimpong, 2018]. For example, in the cartoon by Carlos published in the weekly paper the Mail \& Guardian (Figure 6), South Africa tells the virus to "tsek!", 3 an expression that is a shortened version of the South African slang word "voetsek", 4 which means "get lost!" or "scram!". By contextualising scientific information in a local context and communicating in a local vernacular, the informal register of editorial cartoons affords them the ability to communicate complex scientific communication to audiences in language they understand. This however implies that an element of interpretation will always be present in cartoonists' work. Shapiro, arguably South Africa's best known cartoonist, refers to himself as a "visual columnist" who interprets events "in a personal way": "I'm always working with things that the public knows about and may not know about, and I occasionally start debates" [Dennill, 2017, online].

Objectives and research questions
Our objective with this study was to determine if (and how) South African cartoonists illustrated the novel coronavirus in cartoons related to COVID-19, with a specific focus on the incidence and nature of anthropomorphism as a tool in their visual discourse about the virus.

Based on the theory of caricature which suggests that cartoons represent public sentiment toward pertinent issues at a given point in time [Wiid et al., 2016], we assumed that cartoons about COVID-19, and the characteristics of virus illustrations, would articulate and influence public views, and help shape public perception [Kleeman, 2006; Greenberg, 2002; Panneerselvan, 2020]. Therefore, we

\footnotetext{
${ }^{3}$ See https:/ / www.urbandictionary.com/define.php?term=Tsek.

${ }^{4}$ See https: / / www.urbandictionary.com/define.php?term=Voetsek.
} 


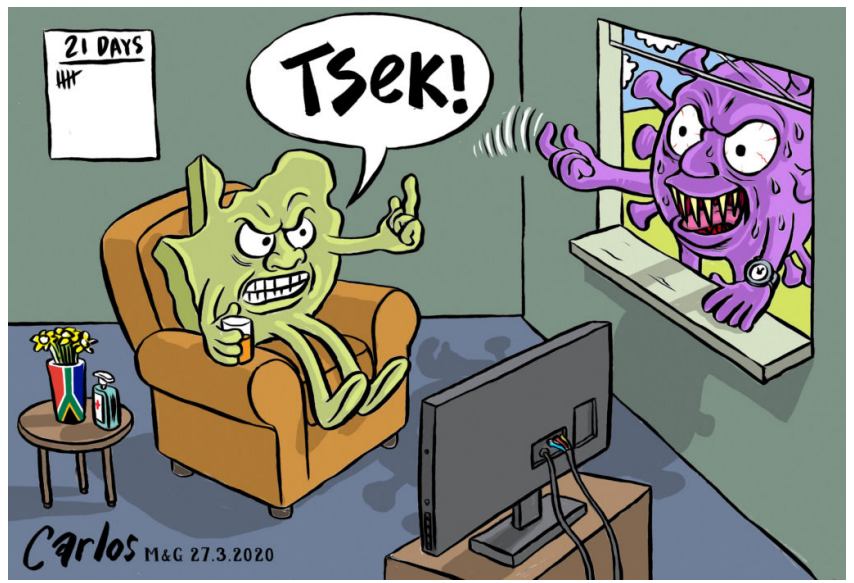

Figure 6. “Tsek!", by Carlos, published in Mail \& Guardian on 27 March 2020. Used with permission.

also examined the emotional tone conveyed by cartoons containing illustrations of the virus.

Our research set out to answer the following research questions:

1. How often do South African editorial cartoonists include illustrations of the novel coronavirus in their editorial cartoons related to the COVID-19 pandemic?

2. What are the most dominant characteristics of their virus drawings in terms of structural shape (morphology) and colour?

3. Do these cartoonists anthropomorphise their virus drawings and, if so, what human characteristics and abilities do they attribute to the virus?

4. What is the overall emotive tone (or sentiment) of the cartoons?

Our study analysed editorial cartoons published in South African newspapers (print and online) during the first five months of 2020, i.e. 1 January to 31 May.

The timeframe for the study starts one day after officials from the WHO in China first reported an outbreak of a new type of coronavirus, on 31 December 2019 [World Health Organisation, 2020]. Over the next few weeks, COVID-19 started spreading around the world, and South Africa's first case was confirmed on 5 March 2020 [Abdool Karim, 2020]. A national, five-week lockdown started on 26 March 2020; followed by a gradual phasing out of lockdown measures over many months.

Using a combination of PressReader ${ }^{5}$ and online news sites as sources of data, we identified 15 South African newspapers that publish single-panel editorial cartoons regularly, jointly publishing the work of 14 cartoonists, as shown in Table 1.

\footnotetext{
${ }^{5}$ See https://www.pressreader.com/.
} 
Table 1. Newspapers and cartoonists included in the current study.

\begin{tabular}{|c|c|c|c|c|}
\hline $\begin{array}{l}\text { Type and } \\
\text { language }\end{array}$ & $\begin{array}{l}\text { Name of } \\
\text { publication }\end{array}$ & Brief description & Cartoonists & Pen name \\
\hline \multirow{4}{*}{$\begin{array}{l}\text { Printed } \\
\text { newspapers } \\
\text { (Afrikaans } \\
\text { language) }\end{array}$} & Die Burger & Daily; regional & Fred Mouton & Fred Mouton \\
\hline & Beeld & Daily; regional & Neil van Vuuren & Neil van Vuuren \\
\hline & Volksblad & Daily; regional & Neil van Vuuren & Neil van Vuuren \\
\hline & Rapport & Weekly; national & Jeremy Nell & Jerm \\
\hline \multirow{9}{*}{$\begin{array}{l}\text { Printed } \\
\text { newspapers } \\
\text { (English) }\end{array}$} & Business Day & Daily; national & Brandan Reynolds & Brandan \\
\hline & Sowetan & Daily; national & Sifiso Yalo & Yalo \\
\hline & The Citizen & Daily; regional & Themba Siwela & Siwela \\
\hline & The Star & Daily; regional & Bethuel Mangena & Mangena \\
\hline & City Press & Weekly, national & $\begin{array}{l}\text { Jack Swanepoel } \\
\text { and John Curtis }\end{array}$ & Dr Jack \& Curtis \\
\hline & Mail \& Guardian & Weekly; national & Carlos Amato & Carlos \\
\hline & $\begin{array}{l}\text { Sunday } \\
\text { Independent }\end{array}$ & Weekly; national & Bethuel Mangena & Mangena \\
\hline & Sunday Times & Weekly; national & Brandan Reynolds & Brandan \\
\hline & Sunday World & Weekly; national & Sifiso Yalo & Yalo \\
\hline \multirow[t]{3}{*}{$\begin{array}{l}\text { Online news } \\
\text { sites }\end{array}$} & Daily Maverick & Online & $\begin{array}{l}\text { Jonathan Shapiro, } \\
\text { Rico Schacherl, } \\
\text { Jack Swanepoel } \\
\text { and John Curtis; } \\
\text { Thulani Ntsong }\end{array}$ & $\begin{array}{l}\text { Zapiro, Rico, } \\
\text { Dr Jack \& Curtis, } \\
\text { 2Lani }\end{array}$ \\
\hline & EWN Online & Online & $\begin{array}{l}\text { Jack Swanepoel } \\
\text { and John Curtis }\end{array}$ & Dr Jack \& Curtis \\
\hline & New Frame & Online & Carlos Amato & Carlos \\
\hline
\end{tabular}

We searched for cartoons in each of these 15 newspapers or news sites in every issue and downloaded all those cartoons that were relevant to the novel coronavirus and the COVID-19 pandemic. From this group of cartoons - as far as we could establish, a census of the entire population of cartoons during this timeframe - we identified cartoons that included a depiction of one or more viruses and drew these as a purposive sample. Guided by a codebook, we coded these cartoons for the characteristics of the virus portrayals (morphology and colour), as well of for the presence of anthropomorphism. In those where anthropomorphism was present, we coded the virus drawings to analyse the type of physical characteristics resembling humans (such as facial features and limbs), emotional states (for example angry, friendly or neutral) and activity (i.e. drawings where the virus appears to be running, climbing, etc.). Finally, we coded all the cartoons containing virus drawings (where anthropomorphism was present or not) for sentiment (or emotional tone).

Two coders collaborated on the development and testing of the codebook. Independent coding of 25 randomly selected cartoons resulted in an overall inter-coder reliability score of $86 \%$ between the two coders, which is higher than the generally required agreement of $80 \%$ [Bayerl and Paul, 2011]. the novel coronavirus in their editorial cartoons related to the COVID-19 pandemic?) we compared the total number of COVID-19-related cartoons (the population) in our 
data set with the number of cartoons containing virus illustrations (in our purposive sample).

A total of 497 editorial cartoons relevant to COVID-19 were published between 1 January and 31 May 2020 in the 15 newspapers listed in Table 1. Of these, 120 (24\%) included an illustration of a coronavirus.

Figure 7 compares the number of COVID-19-related cartoons (published per week) with the number of cartoons that illustrated the virus. Overall, the number of cartoons related to COVID-19 rose sharply during March 2020 once the first case of COVID-19 was confirmed in South Africa and case numbers started to increase. The topic remained of key importance (and had high news value) during April and May, as South Africans had to cope with stringent lockdown regulations. Once the lockdown took effect (from end March), fewer cartoons contained an illustration of the virus. Overall, 377 of the total set of 497 cartoons (76\%) did not include a depiction of the virus. This is because cartoonists responded to the pandemic not only in terms of its scientific dimensions, but also focused on the political response to the pandemic and the associated societal and economic implications. It could therefore be argued that the contextual aspects of the pandemic, which include the politicisation of the outbreak and subsequent policy responses, outweighed the purely scientific elements of its portrayal in editorial cartoons.

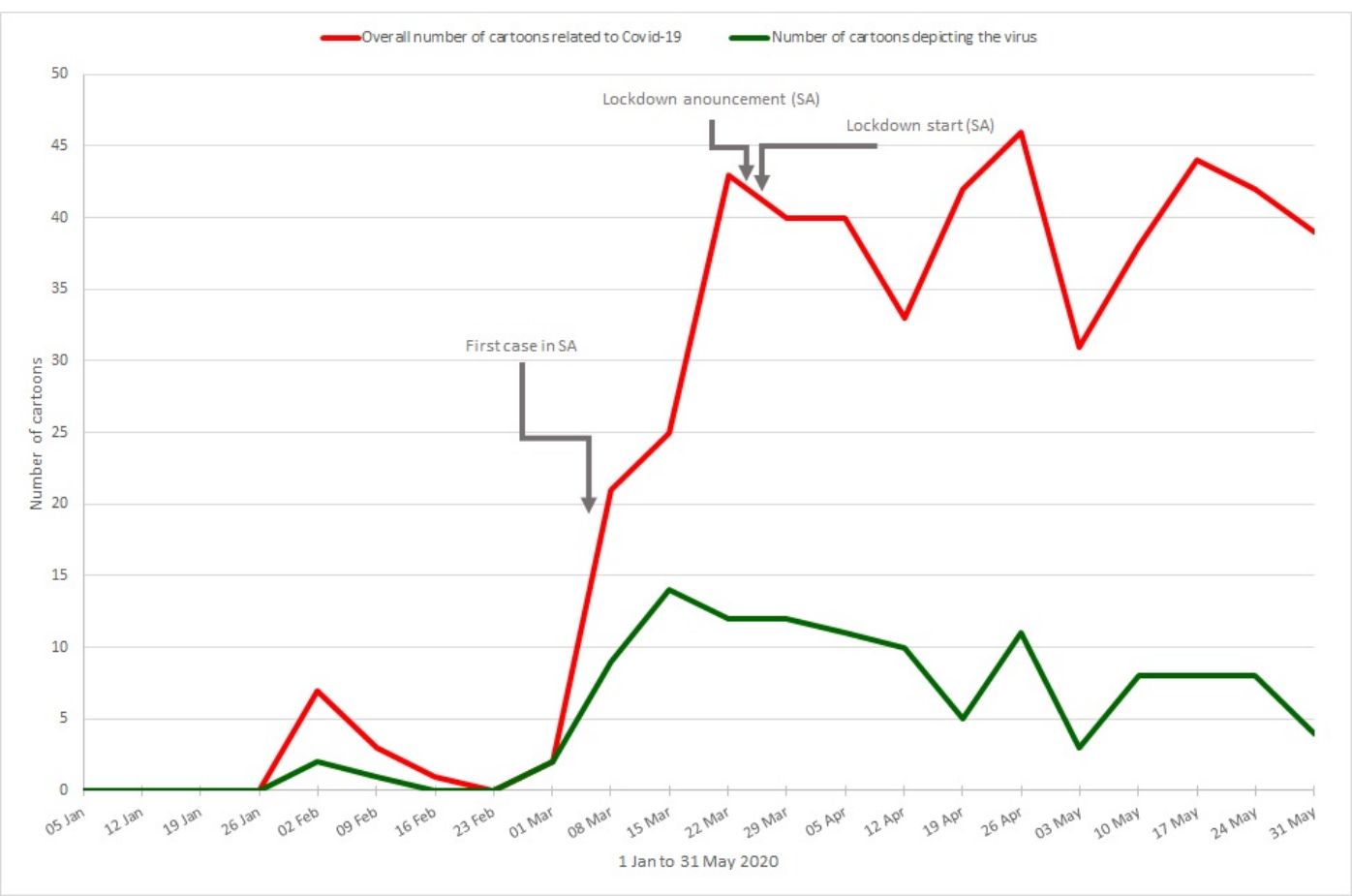

Figure 7. Number of COVID-19-related cartoons compared to cartoons depicting the novel coronavirus.

Our second research question focused on the shapes and colours that cartoonists favoured in their virus drawings.

In terms of the shape, we found that cartoonists almost always used exaggeration when they drew the crown-like halo of the virus, thereby altering the appearance of the virus considerably. An example of such exaggeration of the virus's shape, with 
the purpose of increasing the perception of threat, can already be seen in one of the earliest depictions of the virus in the South African media. In Die Burger's cartoon on 29 January 2020 (see Figure 8). In this cartoon, a threatening and evil-looking coronavirus is attaching itself to a worried-looking (and mask-wearing) planet Earth.

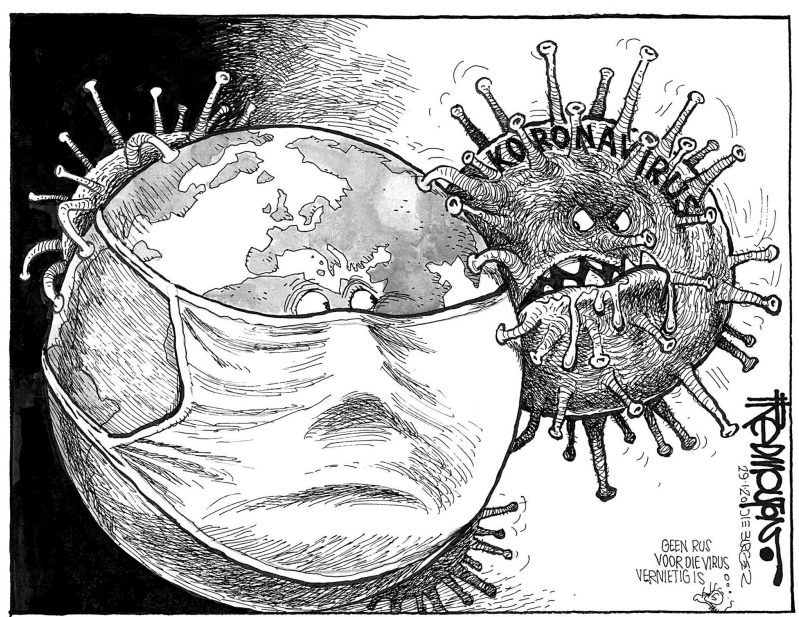

Figure 8. A cartoon by Fred Mouton showing a coronavirus threatening to overtake Earth, published on 29 January 2020 in Die Burger. Used with permission.

In 110 of the 120 cartoons containing a drawing of the virus (i.e. in more than $90 \%$ of virus drawings) we analysed, cartoonists depicted the coronavirus as having enlarged knobs or elongated (even spikey) stalks. In contrast, in electron microscope images, the so-called halo of the coronavirus consists of tiny, rounded blobs (looking almost like a string of beads) that closely surround the central structure of the virus. Examples of such elongated stalks or spikes can be seen in Figures 8 and 11. In cartooning, the exaggeration (or distortion) of physical features is used to make a specific point or convey a specific message. In the case of the coronavirus, the exaggeration of its protrusions could be a way to draw attention to the threat posed by the virus. As noted by Weaving [2020] the image of spherical blobs with spikes somewhat resembles an alien invader.

In terms of the colours that cartoonists chose to illustrate the virus, our results show that they favoured green $(n=42 ; 35 \%)$ or red $(n=40 ; 33 \%)$. Keeping in mind that viruses are essentially monochrome grey, cartoonists could base their colour palette on scientific information (virus electron micrographs or scientific illustrations where 'false' colours have been added), but they also use colour as a visual tool to make their illustrations more persuasive. Their strong preference for green and red (see Figures 9a, b \& c) adds to the rhetoric of the viral threat. In this context, green is a distasteful colour (associated with sickness and slime), while red spells danger, but there is a risk that the overuse of these colours could fuel public fears unnecessarily [Weaving, 2020].

In our third research question, we explored the presence and incidence of anthropomorphism in the virus drawings, as well as the type of human characteristics that cartoonists attributed to the virus. Anthropomorphism was present in more than half of the 120 cartoons where the virus was illustrated ( $n=70$; $58 \%$ ). Figure 10 shows that cartoonists applied anthropomorphism to their drawings throughout the study period. 


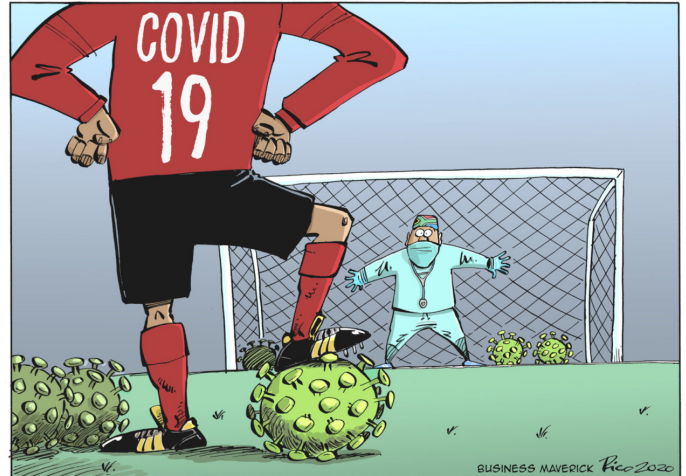

(a)

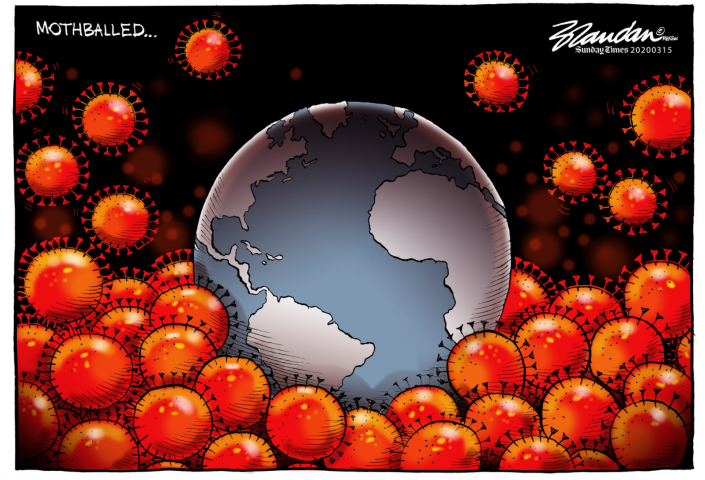

(b)

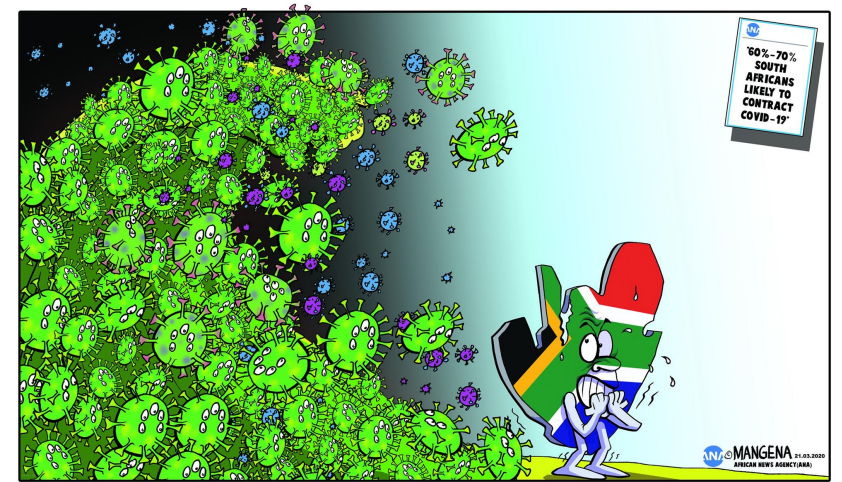

(c)

Figure 9. Green and red dominated as colour choices when cartoonists drew the virus: "COVID-19" (Rico, Daily Maverick, 23 March 2020); "Mothballed" (Brandan, Sunday Times, 15 March 2020) and "Coronavirus in SA (Mangena, The Star, 21 March 2020). Used with permission.

In those cartoons where anthropomorphism was present $(n=70)$, the virus was almost always attributed with typical human facial features such as eyes and/or nose and/or mouth ( $\mathrm{n}=68 ; 97 \%)$. Of these 68 cartoons, 38 (56\%) had visible teeth, while $34(50 \%)$ had human-like limbs (arms/hands and/or legs/feet). In terms of the facial expressions of the virus, most were evil-looking $(n=46 ; 68 \%)$. In a few cases, the virus had a friendly expression $(n=4 ; 6 \%)$ or looked sad $(n=3 ; 4 \%)$, while the rest were neutral. The evil-looking facial expressions were frequently exacerbated by pointy teeth, dripping with slime (see Figure 11 as an example).

We were interested to see how often anthropomorphism was taken to a higher level by giving the virus the ability to speak, crediting it with consciousness and intentionality [Alden, 2004]. In 16 cartoons ( $23 \%$ of the 70 cartoons where the virus was anthropomorphised) the virus "spoke". In 57 of the 70 anthropomorphised virus drawings ( $81 \%)$, the virus performed an activity, such as walking, running, often including threatening behaviour. These types of anthropomorphism are illustrated in two cartoons by Dr Jack \& Curtis (Figure 12a \& b).

The image used in Figure 12a made use of the 'monster' trope and alludes to the dark comedy musical film Little Shop of Horrors (1986). The South African president, Cyril Ramaphosa, is seen to feed the insatiable virus with jobs, the economy, small 


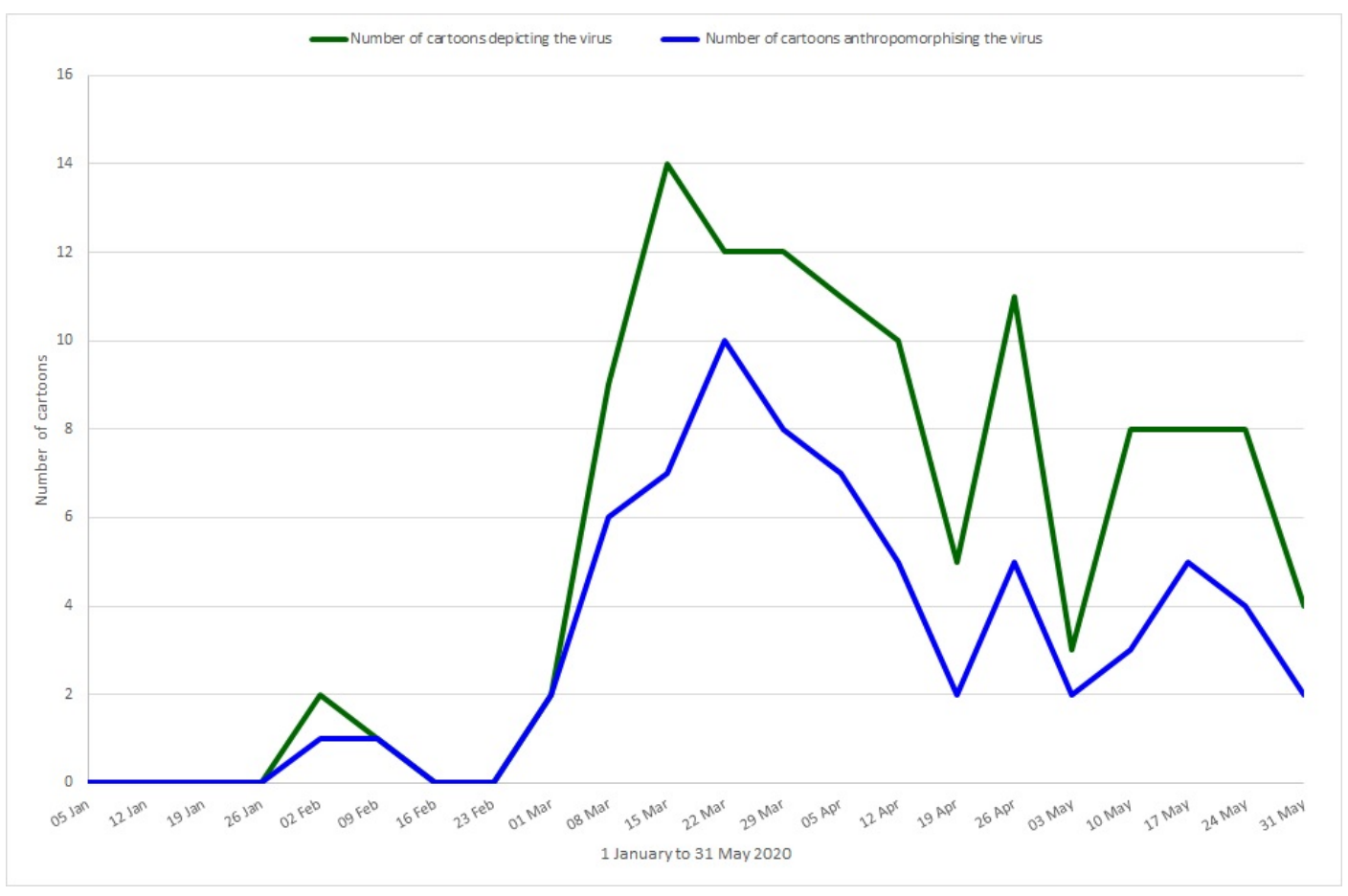

Figure 10. Weekly number of cartoons depicting the novel coronavirus, compared to the number of cartoons where the virus is anthropomorphised.

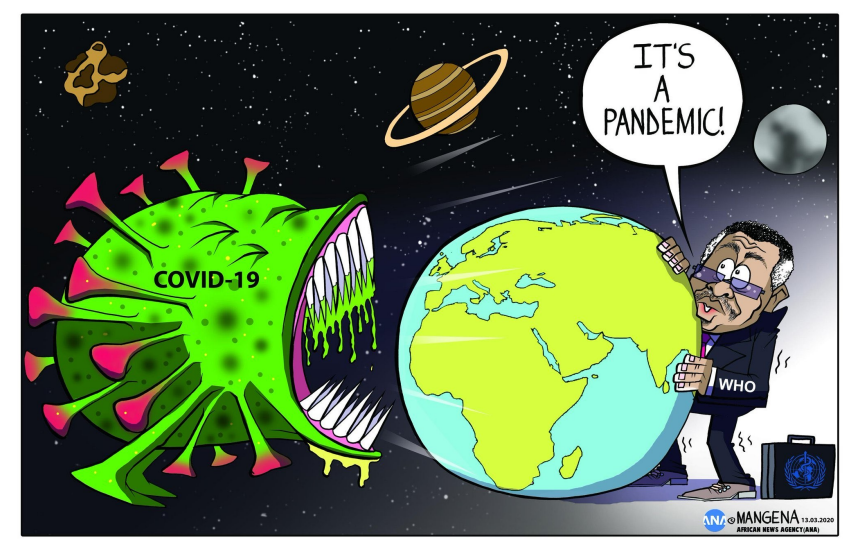

Figure 11. "It's a pandemic", by Mangena, published in The Star on 13 March 2020. Used with permission.

and medium enterprises (SMEs) and individual freedoms. While providing a memorable 'hook' into popular culture, this cartoon links the anthropomorphic depiction of the virus with broader socio-economic concerns about economic devastation and debates about the erosion of democratic freedoms during the stringent lockdown regulations.

Another example of a cartoonist's impression of how the coronavirus intentionally and maliciously disrupted global events such as the Olympic Games, is illustrated in Figure 13.

Research question 4 focused on the overall emotive tone of all the cartoons included in this study where the virus was illustrated $(n=120)$. The most dominant 


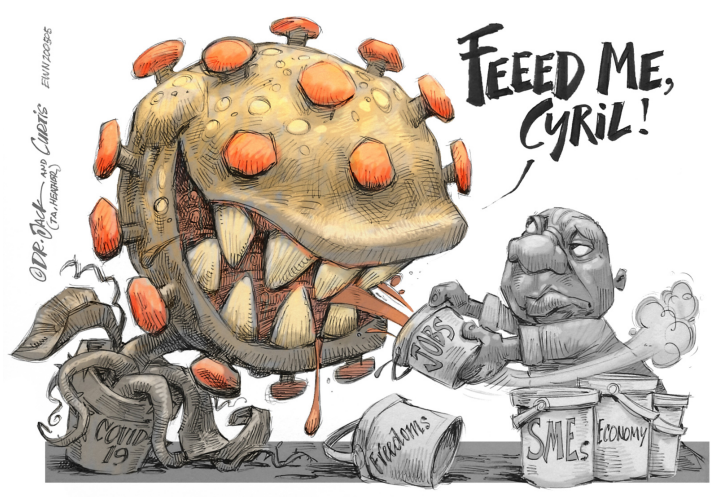

(a)

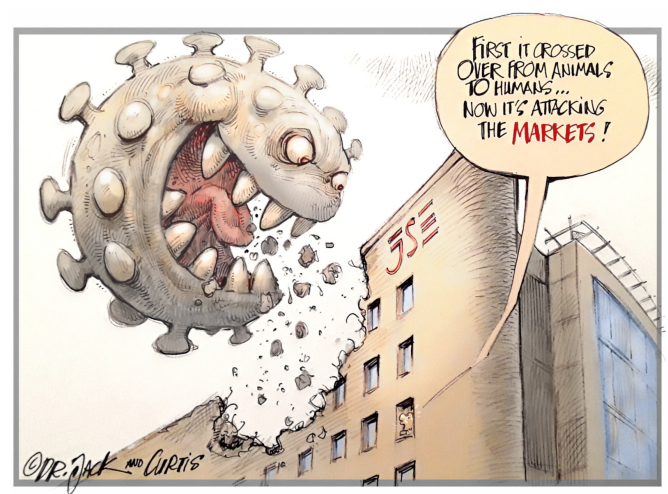

(b)

Figure 12. "Feed me" and "Attacking the JSE" by Dr Jack \& Curtis, published by EWN on 17 March and 5 May 2020 respectively. Used with permission.

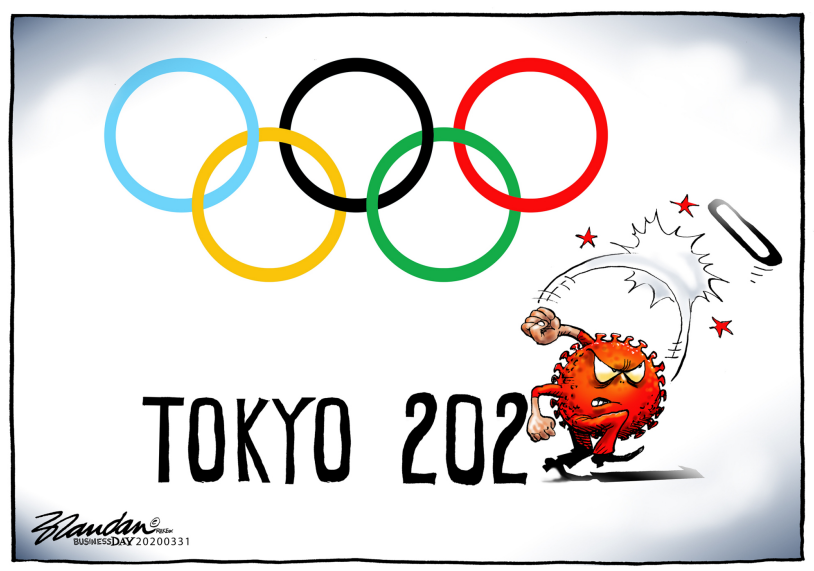

Figure 13. 'Tokyo 2020' by Brandan, published in Business Day, 31 March 2020. Used with permission.

tone was fear $(n=76 ; 63.3 \%)$ as illustrated in Figure 14 . Only $28(23.3 \%)$ of the cartoons where the virus was illustrated had a humorous tone, with the rest $(n=16$; $13.3 \%$ ) considered to be neutral. Cartoonists' limited use of humour when depicting the virus is a reflection on the gravity of the COVID-19 pandemic.

Several of the scary cartoons contained a representation of death in the shape of the grim reaper, visualised in the context of poor communities facing a dual threat of COVID-19 together with poverty and hunger (see Figure 15a) and children who are scared to return to school (see Figure 15b).

As mentioned before, cartoonists frequently commented on the socio-economic impact of the virus on a society that was already in crisis before COVID-19. A cartoon by Zapiro (Figure 16) reflects on the seemingly impossible odds that government's economic rescue plan could succeed when faced with high levels of poverty, unemployment and inequality. One of the boulders rushing downhill and threatening to crush this plan is labelled "apartheid-style lockdown". This refers to the heavy-handed enforcement of lockdown regulations and abuse of power by the policy and army, including humiliation of citizens for minor infringements, a high 
number of arrests and several fatalities that made the headlines during the initial weeks of the lockdown period.

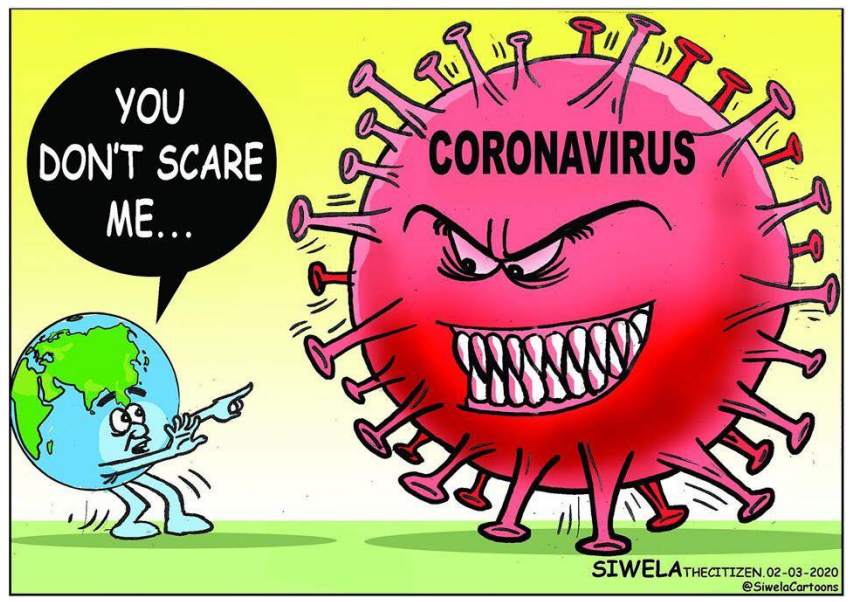

Figure 14. "You don't scare me" by Siwela, published in The Citizen, 2 March 2020. Used with permission.

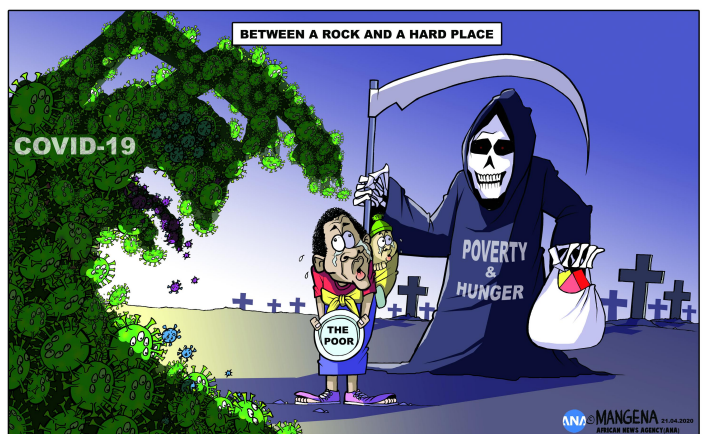

(a)

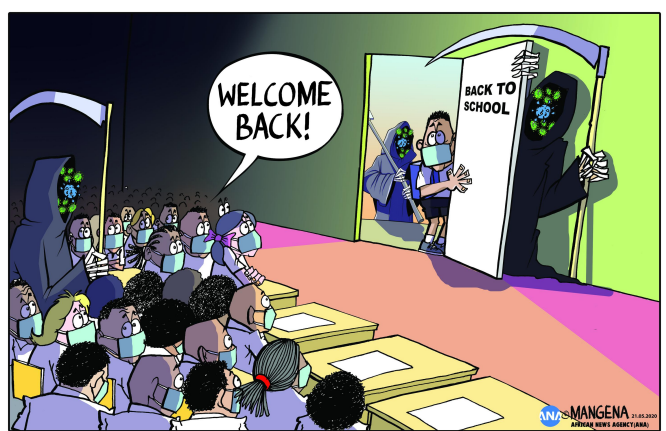

(b)

Figure 15. "Between a rock and a hard place" and "Back to School", by Mangena, published in The Star on 21 April and 21 May 2020 respectively.

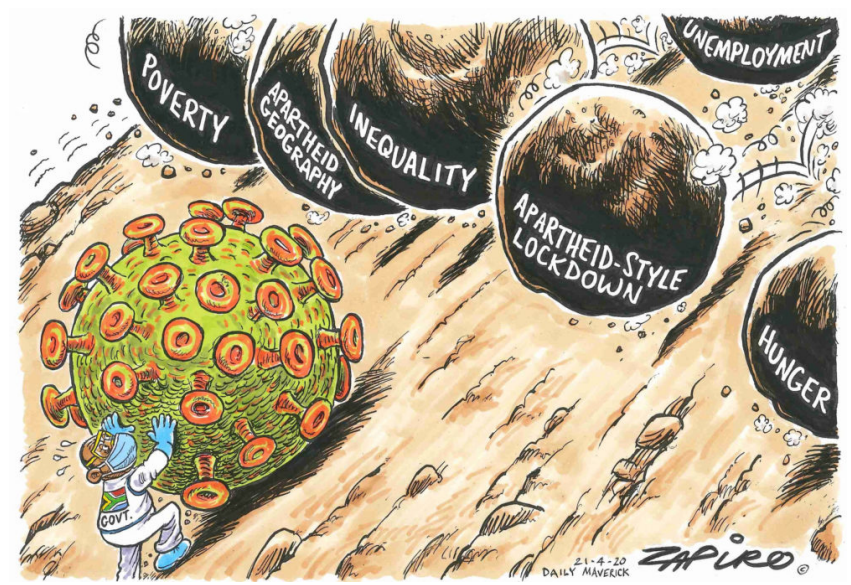

Figure 16. "Rumblings", by Zapiro, published in Daily Maverick on 21 April 2020. Used with permission. (c) 2020-2020 Zapiro (all rights reserved). 
Editorial cartoons play an important role in the public communication of science as they can communicate complex scientific information in an accessible, visual way and within a context that is relevant to the readers of that publication. Furthermore, cartoons provide a vehicle to dispel disinformation in language that resonate with audiences' lived experience and contexts. The fact that the majority of editorial cartoons during our study period did not depict the virus as such directly, but related aspects such as its socio-economic and political impacts, suggests that science communication in this context needs to be defined more broadly to encompass not only the transmission (in visual form) of scientific facts, but also the social, economic and political dimensions of scientific events and developments, in this case the impact of a devastating pandemic on a highly unequal society.

Cartoons, despite their location within journalistic discourse, are however not value-free, objective representations of reality or descriptions of scientific facts. They are, by their very nature as artistic expressions, interpretations of political, social and scientific reality. For this reason, tools such as anthropomorphism are important to consider as they provide a glimpse into the prevailing public attitudes and perceptions around a set of scientific facts, while cartoons, at the same time, help to shape public attitudes and perceptions.

Given the prevalence of disinformation during the so-called COVID-19 'infodemic', editorial cartoons can be read as metaphorical expressions of broader anxieties, fears and (mis)conceptions. Our analysis found that cartoonists' depictions of the coronavirus largely evoked emotions of fear and danger. The images were rendered in exaggerated fashion (e.g. an emphasis on spikes) or striking colours (often red, signalling threat and danger) and where anthropomorphic elements were used, these often served the function of ascribing agency and intentionality to the virus - heightening not only the element of threat, but also possibly diminishing the human agency that may be used to counter it.

These representations are not intended to be taken literally. Rather, they provide symbolic and metaphorical interpretations of the virus within a specific cultural, economic and political context, intended to resonate with broader journalistic discourses and historical antecedents such as the HIV / Aids pandemic. The imagery therefore not only represents the virus itself, but public attitudes, responses and emotions - primary among them, our analysis suggests, that of fear and threat.

\section{Concluding remarks}

Our research shows that South African cartoonists do include science-related issues in their work and have made a notable contribution to media content since news about the novel coronavirus and associated COVID-19 pandemic surfaced and gained momentum. While their illustrations are not scientifically accurate, they are persuasive and rich in visual rhetoric and contribute to the creation of meaning around the virus.

In line with earlier research on cartoons as a form of rhetoric [Medhurst and DeSousa, 1981] and the power of visual material [Joffe, 2008], it is reasonable to conclude that, during a time of crisis, editorial cartoons increase and influence public interest and debate in science-related topics. Our understanding of the role of fear in persuasion [e.g. Dillard and Anderson, 2004], suggests that the dominant 
emotional tone of fear contributes to the persuasive effect of these cartoons that would add to public concern and anxiety about the coronavirus. Therefore, as a form of social commentary that is designed to provoke, these cartoons could be excellent triggers for public dialogue about science-related issues and social impacts during a health crisis.

We conclude that editorial cartoons are important for research and practice of science communication not only because they provide a way to disseminate information, but also because they are useful sources of data to gauge public sentiments and perceptions, especially during a public health pandemic.

Future research could build on this initial exploratory work, to include interviews with cartoonists to gain a better understanding of how they engage with science-related topics and how they make choices when it comes to illustrating scientists and science concepts. Also, focus groups with diverse groups of newspapers readers could shed light on how people respond to science-themed editorial cartoons and what messages they take away after engaging with these cartoons.

Acknowledgments

\section{References}

This work is based on the research supported by the South African National Institute for the Humanities and Social Sciences.

Abdool Karim, S. S. (2020). 'The South African response to the pandemic'. New England Journal of Medicine 382 (24), e95. https://doi.org/10.1056/nejmc2014960.

Ackermann, H. W. (2011). 'The first phage electron micrographs'. Bacteriophage 1 (4), pp. 225-227. https: //doi.org/10.4161/bact.1.4.17280.

Adams, S. R., Mackey, M. R., Ramachandra, R., Palida Lemieux, S. F., Steinbach, P., Bushong, E. A., Butko, M. T., Giepmans, B. N. G., Ellisman, M. H. and Tsien, R. Y. (2016). 'Multicolor electron microscopy for simultaneous visualization of multiple molecular species'. Cell Chemical Biology 23 (11), pp. 1417-1427. https://doi.org/10.1016/j. chembiol.2016.10.006.

Airenti, G. (2018). 'The development of anthropomorphism in interaction: intersubjectivity, imagination and theory of mind'. Frontiers in Psychology 9. https://doi.org/10.3389/fpsyg.2018.02136.

Alcabes, P. (2009). Dread: how fear and fantasy have fuelled epidemics from the black death to avian flu. New York, NY, U.S.A.: Public Affairs.

Alden, A. (2004). 'Anthropomorphism in New Yorker dog cartoons across the twentieth century'. Doctoral dissertation. CA, U.S.A.: Alliant International University.

Almeida, J. D. and Tyrrell, D. A. J. (1967). 'The morphology of three previously uncharacterized human respiratory viruses that grow in organ culture'. Journal of General Virology 1 (2), pp. 175-178. https://doi.org/10.1099/0022-1317-1-2-175.

Arbilly, M. and Lotem, A. (2017). 'Constructive anthropomorphism: a functional evolutionary approach to the study of human-like cognitive mechanisms in animals'. Proceedings of the Royal Society B: Biological Sciences 284 (1865), p. 20171616. https://doi.org/10.1098/rspb.2017.1616.

Artenstein, A. W. (2012). 'The discovery of viruses: advancing science and medicine by challenging dogma'. International Journal of Infectious Diseases 16 (7), e470-e473. https://doi.org/10.1016/j.ijid.2012.03.005. 
Ball, C. S. (1966). 'The early history of the compound microscope'. Bios 37 (2), pp. 51-60. URL: https://www. jstor.org/stable/4606667.

Bauer, M. W. and Gaskell, G. (1999). 'Towards a paradigm for research on social representations'. Journal for the Theory of Social Behaviour 29 (2), pp. 163-186. https://doi.org/10.1111/1468-5914.00096.

Bayerl, P. S. and Paul, K. I. (2011). 'What determines inter-coder agreement in manual annotations? A meta-analytic investigation'. Computational Linguistics 37 (4), pp. 699-725. https://doi.org/10.1162/coli_a_00074.

Breedlove, B. and Arguin, P. M. (2015). 'Anthropomorphism to zoonoses: two inevitable consequences of human-animal relationships'. Emerging Infectious Diseases 21 (12), pp. 2282-2283. https://doi .org/10.3201/eid2112.ac2112.

Brits, E. (12th June 2020). 'Wat as corona rooi en soos stekelrige knapsekêrels was?' Vrye Weekblad. URL: https: //www . vryeweekblad.com/menings-en-debat/202006-11-wat-as-corona-rooi-en-soos-stekelrige-knapsekrels-was/.

Bruni, D., Perconti, P. and Plebe, A. (2018). 'Anti-anthropomorphism and its limits'. Frontiers in Psychology 9, p. 2205. https://doi .org/10.3389/fpsyg. 2018.02205.

Buiani, R. (2014). 'Innovation and compliance in making and perceiving the scientific visualization of viruses'. Canadian Journal of Communication 39 (4), pp. 539-556. https://doi.org/10.22230/cjc.2014v39n4a2738.

Byrne, J., Grace, M. and Hanley, P. (2009). 'Children's anthropomorphic and anthropocentric ideas about micro-organisms'. Journal of Biological Education 44 (1), pp. 37-43. https://doi.org/10.1080/00219266.2009.9656190.

Campbell, O. (21st February 2018). 'Under Victorian microscopes, an enchanted world'. JSTOR Daily. URL: https://daily.jstor.org/victorian-microscope-enchanted-world/.

Chatterjee, S. (30th June 2020). 'Making the invisible visible: how we depict COVID-19'. LSE COVID-19 blog. URL: https://blogs. Ise.ac.uk/covid19/202 0/06/30/making-the-invisible-visible-how-we-depict-covid-19/.

Connelly, M. and Macleod, C. (2003). 'Waging war: discourses of HIV / AIDS in South African media'. African Journal of AIDS Research 2 (1), pp. 63-73. https://doi.org/10.2989/16085906.2003.9626560.

Davies, J. (2010). 'Anthropomorphism in science'. EMBO reports 11 (10), pp. 721-721. https://doi.org/10.1038/embor.2010.143.

Dennill, B. (3rd December 2017). 'Interview: Zapiro - art and activism, or all the news that's fit to interpret'. Participate. URL: http://www. brucedennill.co.za /book-interview-zapiro-art-activism-news-thats-fit-interpret/.

DeSousa, M. A. and Medhurst, M. J. (1982). 'Political cartoons and american culture: significant symbols of campaign 1980'. Studies in Visual Communication 8 (1), pp. 84-97. URL: https ://repository . upenn. edu/svc/vol8/iss1/9.

Dillard, J. P. and Anderson, J. W. (2004). 'The role of fear in persuasion'. Psychology and Marketing 21 (11), pp. 909-926. https://doi .org/10.1002/mar. 20041.

Domínguez, M. (2014). 'Einstein versus neutrinos: the two cultures revisited with the media coverage of a scientific news item in cartoons'. Science Communication 36 (2), pp. 248-259. https: //doi .org/10.1177/1075547012472685.

DoRozario, R. C. (2006). 'The consequences of Disney anthropomorphism: animated, hyper-environmental stakes in Disney entertainment'. Femspec 7 (1), pp. 51-65.

Entertainment Reporter (23rd March 2020). 'Sizwe Dhlomo ruffles feathers after saying 'rich people' brought COVID-19 to SA'. IOL. URL: https://www. iol . co .za/entertainment/celebrity-news/local/sizwe-dhlomo-ruffles-feather s-after-saying-rich-people-brought-covid-19-to-sa-45393501. 
Epley, N., Waytz, A., Akalis, S. and Cacioppo, J. T. (2008). 'When we need a human: motivational determinants of anthropomorphism'. Social Cognition 26 (2), pp. 143-155. https://doi.org/10.1521/soco.2008.26.2.143.

Epley, N., Waytz, A. and Cacioppo, J. T. (2007). ‘On seeing human: A three-factor theory of anthropomorphism'. Psychological Review 114 (4), pp. 864-886. https://doi.org/10.1037/0033-295x.114.4.864.

Farinella, M. (2018). 'The potential of comics in science communication'. JCOM 17 (01), Y01. https://doi.org/10.22323/2.17010401.

Fildes, P. G. (1951). 'Leeuwenhoek lecture - the evolution of microbiology'. Proceedings of the Royal Society of London. Series B - Biological Sciences 138 (890), pp. 65-74. https://doi.org/10.1098/rspb.1951.0005.

Frumkin, R. (18th May 2020). 'How to draw the coronavirus'. The Paris Review. URL: https://www . theparisreview .org/blog/2020/05/18/how-to-draw-thecoronavirus/.

Gaiter, C. (9th April 2020). 'Visualizing the virus'. The Conversation Africa. URL: https://theconversation.com/visualizing-the-virus-135415.

Gale, J. (31st January 2020). 'Here are the first images of how coronavirus replicates in cells'. Bloomberg.

URL: https://www . bloomberg.com/news/articles/2020-01-31/here-are-the -first-images-of-how-coronavirus-replicates-in-cells.

Gest, H. (2004). 'The discovery of microorganisms by Robert Hooke and Antoni van Leeuwenhoek, fellows of the Royal Society'. Notes and Records of the Royal Society of London 58 (2), pp. 187-201. https://doi .org/10.1098/rsnr.2004.0055.

Giarelli, E. and Tulman, L. (2003). 'Methodological issues in the use of published cartoons as data'. Qualitative Health Research 13 (7), pp. 945-956. https://doi.org/10.1177/1049732303253545.

Goldsmith, C. S. and Miller, S. E. (2009). 'Modern uses of electron microscopy for detection of viruses'. Clinical Microbiology Reviews 22 (4), pp. 552-563. https://doi.org/10.1128/cmr.00027-09.

Green, M. J. and Myers, K. R. (2010). 'Graphic medicine: use of comics in medical education and patient care'. BMJ 340, p. c863.

https://doi.org/10.1136/bmj.c863.

Greenberg, J. (2002). 'Framing and temporality in political cartoons: a critical analysis of visual news discourse'. Canadian Review of Sociology/Revue canadienne de sociologie 39 (2), pp. 181-198. https://doi.org/10.1111/j.1755-618x.2002.tb00616.x.

Hand, E. (14th March 2016). 'Iron-eating fungus disintegrates rocks with acid and cellular knives'. Science. https://doi .org/10.1126/science . aaf4184.

Hansen, B. (1997). 'The image and advocacy of public health in American caricature and cartoons from 1860 to 1900'. American Journal of Public Health 87 (11), pp. 1798-1807. https://doi.org/10.2105/ajph.87.11.1798.

Hight, S. R. (2017). 'Does anthropomorphism affect people's ability to distinguish fact from fiction?' Masters' thesis. Dunedin, New Zealand: University of Otago. URL: http: //hdl . handle. net/10523/7604.

Höijer, B. (2011). 'Social representation theory: a new theory for media research'. Nordicom Review 32 (2), pp. 3-16. https://doi .org/10.1515/nor-2017-0109.

Horne, F. J. (2011). 'Getting the message across: a critical consideration of selected political cartoons on AIDS in South Africa'. NAWA: Journal of Language and Communication 5 (2), pp. 24-43.

URL: https://www . questia.com/library/journal/1G1-300885601/getting-t he-message-across-a-critical-consideration. 
Joffe, H. (2008). 'The power of visual material: persuasion, emotion and identification'. Diogenes 55 (1), pp. 84-93. https://doi.org/10.1177/0392192107087919.

Kelley-Romano, S. and Westgate, V. (2007). 'Blaming Bush, an analysis of political cartoons following hurricane Katrina'. Journalism Studies 8 (5), pp. 755-773. https://doi.org/10.1080/14616700701504724.

Kim, S. and McGill, A. L. (2011). 'Gaming with Mr. Slot or gaming the slot machine? Power, anthropomorphism and risk perception'. Journal of Consumer Research 38 (1), pp. 94-107. https: //doi .org/10.1086/658148.

Kleeman, G. (2006). 'Not just for fun: using cartoons to investigate geographical issues'. New Zealand Geographer 62 (2), pp. 144-151. https://doi.org/10.1111/j.1745-7939.2006.00057.x.

Knieper, T. (2007). 'Political cartoon'. In: Encyclopaedia of governance. Ed. by M. Bevir. Thousand Oaks, CA, U.S.A.: SAGE Publications Inc.

Kotzé, D. (1988). 'Cartoons as a medium of political communication'. Communicatio 14 (2), pp. 60-70. https://doi.org/10.1080/02500168808537742.

McNicol, S. (2017). 'The potential of educational comics as a health information medium'. Health Information E Libraries Journal 34 (1), pp. 20-31. https://doi.org/10.1111/hir.12145.

Medhurst, M. J. and DeSousa, M. A. (1981). ‘Political cartoons as rhetorical form: a taxonomy of graphic discourse'. Communication Monographs 48 (3), pp. 197-236. https://doi.org/10.1080/03637758109376059.

Milman, O. (15th January 2016). 'Anthropomorphism: how much humans and animals share is still contested'. The Guardian.

URL: https://www theguardian.com/science/2016/jan/15/anthropomorphis m-danger-humans-animals-science.

Moodley, P. and Lesage, S. S. (2019). 'A discourse analysis of Ebola in South African newspapers (2014-2015)'. South African Journal of Psychology 50 (2), pp. 158-169. https://doi.org/10.1177/0081246319868656.

Moscovici, S. (1961). La psychanalyse, son image et son public. Paris, France: Presses Universitaires de France.

- (1984). 'The phenomenon of social representations'. In: Social representations. Ed. by R. M. Farr and S. Moscovici. Cambridge, U.K.: Cambridge University Press, pp. 3-69.

Nerlich, B. (3rd April 2020). 'Images in the time of coronavirus'. University of Nottingham blog. URL: https://blogs.nottingham.ac.uk/makingsciencepubli c/2020/04/03/images-in-the-time-of-coronavirus/.

Oduro-Frimpong, J. (2018). 'Glocalization and popular media: the case of Akosua political cartoons'. In: Global dialectics in intercultural communication: case studies. Ed. by J. A. Drzewiecka and T. K. Nakayama. New York, NY, U.S.A.: Peter Lang Publishing Inc.

Panneerselvan, A. S. (30th March 2020). 'No laughing matter'. The Hindu. URL: https://www . thehindu.com/opinion/Readers-Editor/no-laughing-mat ter/article31200218. ece.

Philp, K. (6th May 2020). 'The virus is not our enemy plotting against us'. UCF Today. URL: https://www. ucf . edu/news/the-virus-is-not-our-enemy-plott ing-against-us/.

Porubanova, M. and Guthrie, S. (22nd May 2020). 'Humanizing the coronavirus as an invisible enemy is human nature'. The Conversation Africa.

URL: https://theconversation.com/humanizing-the-coronavirus-as-an-in visible-enemy-is-human-nature-138497. 
Richmond, P. A. (1954). 'American attitudes toward the germ theory of disease (1860-1880)'. Journal of the History of Medicine and Allied Sciences IX (4), pp. 428-454. https://doi.org/10.1093/jhmas/ix.4.428.

Roosth, S. (2009). 'Screaming yeast: sonocytology, cytoplasmic milieus and cellular subjectivities'. Critical Inquiry 35 (2), pp. 332-350. https://doi.org/10.1086/596646.

Schell, H. (1997). 'Outburst! A chilling true story about emerging-virus narratives and pandemic social change'. Configurations 5 (1), pp. 93-133. https://doi.org/10.1353/con.1997.0006.

Schlozman, S. (3rd October 2014). 'The personification of Ebola — fighting the true infection'. Psychology Today.

URL: https://www . psychologytoday .com/za/blog/grand-rounds/201410/the -personification-ebola-fighting-the-true-infection.

Sismondo, S. (2010). 'The social construction of scientific and technical realities'. In: An introduction to science and technology studies. Ed. by S. Sismondo. 2nd ed. U.K.: Blackwell, pp. 57-71.

Smith, H. J. (2018). 'Microbes eat rocks and leave carbon dioxide'. Science 360 (6385), p. 166. https://doi.org/10.1126/science.360.6385.166-a.

Talib, A., Khan, A. A., Ahmed, H. and Jilani, G. (2017). 'The nano-magnetic dancing of bacteria hand-in-hand with oxygen'. Brazilian Archives of Biology and Technology 60, e17160769. https: //doi .org/10.1590/1678-4324-2017160769.

Tan, T., Yee, C. H., Ng, C. F. and Teoh, J. Y. C. (2020). 'COVID-19 and the history of antiseptic surgery: how to tackle these little beasts'. Hong Kong Medical Journal 26 (3), pp. 258-259. https: //doi .org/10.12809/hkmj208617.

Tarver, T., Woodson, D., Fechter, N., Vanchiere, J., Olmstadt, W. and Tudor, C. (2016). 'A novel tool for health literacy: using comic books to combat childhood obesity'. Journal of Hospital Librarianship 16 (2), pp. 152-159. https://doi.org/10.1080/15323269.2016.1154768.

Tatalovic, M. (2009). 'Science comics as tools for science education and communication: a brief, exploratory study'. JCOM 8 (04), A02. URL: https://jcom. sissa.it/archive/08/04/Jcom0804\%282009\%29A02.

The Economist (31st March 2020). 'Worth a thousand words: the power of newspaper cartoons during a public health crisis'. The Economist. URL: https://www . economist. com/prospero/2020/03/31/the-power-of-news paper-cartoons-during-a-public-health-crisis.

Tomes, N. (1990). 'The private side of public health: sanitary science, domestic hygiene and the germ theory, 1870-1900'. Bulletin of the History of Medicine 64 (4), pp. 509-539. URL: https://www . jstor.org/stable/44443182.

- (1997). 'American attitudes toward the germ theory of disease: Phyllis Allen Richmond revisited'. Journal of the History of Medicine and Allied Sciences 52 (1), pp. 17-50. https://doi.org/10.1093/jhmas/52.1.17.

- (1999). The gospel of germs: men, women and the microbe in American life. Cambridge, MA, U.S.A.: Harvard University Press.

Ulaby, N. (5th April 2020). 'Little demons, death and biting dogs: how we picture disease'. NPR. URL: https://www. npr.org/2020/04/05/823949176/little-dem ons-death-and-biting-dogs-how-we-picture-disease.

Wald, P., Tomes, N. and Lynch, L. (2002). 'Contagion and culture'. American Literary History 14 (4), pp. 617-624. URL: https://www. jstor.org/stable/3568018.

Waytz, A., Morewedge, C. K., Epley, N., Monteleone, G., Gao, J.-H. and Cacioppo, J. T. (2010). ‘Making sense by making sentient: effectance motivation increases anthropomorphism'. Journal of Personality and Social Psychology 99 (3), pp. 410-435. https://doi.org/10.1037/a0020240. 
Weaving, S. (30th March 2020). 'Scary red or icky green? We can't say what colour coronavirus is and dressing it up might feed fears'. The Conversation Africa.

URL: https://theconversation.com/scary-red-or-icky-green-we-cant-say -what-colour-coronavirus-is-and-dressing-it-up-might-feed-fears-134 380.

Weldon, R. A. (2001). 'An "urban legend" of global proportion: an analysis of nonfiction accounts of the Ebola virus'. Journal of Health Communication 6 (3), pp. 281-294. https://doi .org/10.1080/108107301752384451.

Wigston, D. (2002). 'Aids and political cartoons: a case study'. Communicatio 28 (2), pp. 74-94. https://doi.org/10.1080/02500160208537944.

Wiid, R., Grant, P. S., Mills, A. J. and Pitt, L. F. (2016). 'No joke: understanding public sentiment toward selling and salespeople through cartoon analysis'. Marketing Theory 16 (2), pp. 171-193. https://doi.org/10.1177/1470593115607940.

Wood, M. (2019). 'The potential for anthropomorphism in communicating science: inspiration from Japan'. Cultures of Science 2 (1), pp. 23-34. https://doi.org/10.1177/209660831900200103.

World Health Organisation (20th January 2020). Novel Coronavirus (2019-nCoV) situation report - 1. URL: https://www. who.int/docs/default-source/corona viruse/situation-reports/20200121-sitrep-1-2019-ncov.pdf.

\section{Authors}

Marina Joubert is a researcher at the South African Research Chair in Science Communication \& Centre for Research on Evaluation, Science and Technology, Stellenbosch University, South Africa. Her research interests focus on scientists' role in public communication of science, online interfaces between science and society, and the use of visual tools to engage the public with science. Twitter: @marinajoubert. E-mail: marinajoubert@sun.ac.za.

Herman Wasserman is a Professor of Media Studies and Director of the Centre for Film and Media Studies at the University of Cape Town, South Africa. He has published and presented widely on misinformation in Africa, including presentations to the World Health Organization. He is a Fellow of the International Communication Association and an elected member of the Academy of Science of South Africa. E-mail: herman.wasserman@uct.ac.za.

\section{How to cite}

Joubert, M. and Wasserman, H. (2020). 'Spikey blobs with evil grins: understanding portrayals of the coronavirus in South African newspaper cartoons in relation to the public communication of science'. JCOM 19 (07), A08. https://doi.org/10.22323/2.19070208. 